НАУКОВИЙ ВІСНИК

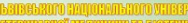

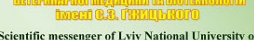

sientific messenger of Lviv National University
Veterinary Medicine and Biotechnologites

(1)

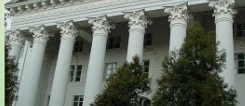

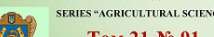

Том 21 № 91

2019
Науковий вісник Дьвівського національного університету ветеринарної медицини та біотехнодогій імені С.3. Гжицького. Серія: Сідьськогосподарські науки

Scientific Messenger of Lviv National University of Veterinary Medicine and Biotechnologies.

Series: Agricultural sciences

UDC 575.113:577.21:636.05

\title{
Influence of ecological and geographical features of breeding brown Carpathian rocks on its genetic structure
}

\author{
V.Y. Bodnaruk, L.I. Muzyka, A.J. Zhmur, T.V. Orikhivskyj \\ Stepan Gzhytskyi National University of Veterinary Medicine and Biotechnologies Lviv, Ukraine
}

Article info

Received 19.09.2019

Received in revised form 17.10.2019

Accepted 18.10.2019

Stepan Gzhytskyi National University of Veterinary Medicine and Biotechnologies Lviv, Pekarskaya Str., 50, Lviv, 79010, Ukraine.

Tel: $:+38-032-239-26-82$

E-mail:bodnaruk.vol@gmail.com
Bodnaruk, V.Y., Muzyka, L.I., Zhmur, A.J., \& Orikhivskyj, T.V. (2019). Influence of ecological and geographical features of breeding brown Carpathian rocks on its genetic structure. Scientific Messenger of Lviv National University of Veterinary Medicine and Biotechnologies. Series: Agricultural sciences, 21(91), 103-107. doi: 10.32718/nvlvet-a9118

Studying the genetic structure of cattle makes it possible to characterize it by molecular genetic markers, which in the future enable effective breeding work with animals breed to achieve the desired characteristics. Lately is becoming more apparent the need to preserve genetic diversity namely due to the peculiarities of breeding in different ecological and geographical regions. Therefore, we conducted an investigation of the genetic structure of animals of pure-bred Brown Carpathian (BC), Schwyz (S) breeds, their mixtures of the first (F1) generation $(1 / 2 B C+1 / 2 S)$, Brown Carpathian with a share of hereditary breed of Schwyz breed up to 50 and more than 50\%, as well as Brown Carpathian, raised in flat and mountain farms. Genetic structure was evaluated by genetically determined polymorphism of groups of genetic-biochemical systems. Of the 14 investigated loci that encode proteins and blood enzymes, polymorphism was identified in five loci, namely: transferrin (Tf), ceruloplasmin (Cr), amylase-1 (Am-1), hemoglobin (Hb), and purine nucleoside phosphorylase (NP). As a result of population-genetic analysis of polymorphic loci of proteins and enzymes of blood in animals of Brown Carpathian breed the following data were obtained:the highest level of heterozygosity $(H)$ was found at the transferrin locus - 95\%, the lowest - at the hemoglobin locus 9.5\%.The heterozygosity at the ceruloplasmin locus was $68 \%$. Evaluation of heterozygosity at the purinnucleoside phosphorylase locus was not possible because part of the animals with the NP-H (high activity) phenotype could carry a low activity variant in the heterozygous state. For all polymorphic systems in the Brown Carpathian breed genotype frequency distribution was in a balanced state according to HardyWeinberg law, except for the transferrin locus, where a statistically significant deficiency of homozygotes $(P>0.95)$ in the most common allelic variants is detected. Analysis of the dendrogram showed that groups of animals of Brown Carpathian breed with different proportion of hereditary Schwyz form one cluster that is clearly differentiated from purebred schwyzes. First-generation domestic animals $\left(F_{1}\right)$, by genetic structure, are significantly closer to the maternal Brown Carpathian breed than to the Schwyz one. Thus, the data obtained indicate that the specific characteristic of Brown Carpathian breed may be a relatively increased breeding value of a number of allelic interlocal associations, in which the loci of the geneticbiochemical systems are involved in one way or another. Genetic analysis of these systems showed the presence in the breed of its specific features, which are specific to it.

Key words: molecular genetic markers, genotype, gene pool, polymorphism, capsaicin, somatotropin, myostatin.

\section{Вплив еколого-географічних особливостей розведення бурої карпатської породи на її генетичну структуру}

\author{
В.С. Боднарук, Л.І. Музика, А.Й. Жмур, Т.В. Оріхівський
}

Львівський начіональний університет ветеринарної медицини та біотехнологій імені С.3. Гжицького, м. Львів, Україна 
Вивчення генетичної структури великої рогатої худоби дає змогу охарактеризувати ї̈ за молекулярно-генетичними маркерами, які в подальшому дають можливість проведення ефективної селекційної роботи з породами тварин, спрямованої на досягнення бажаних ознак. Останнім часом стає все більш очевидною необхідність збереження генетичної різноманітності, а саме в зв'язку з особливостями розведення в різних еколого-географічних регіонах. Тому нами було проведено дослідження генетичної структури тварин чистопородної бурої карпатської (БК), швіцької порід (Ш), їх помісей першого (F $)$ покоління (1/2БК+1/2Ш), бурої карпатської з часткою спадковості швіцької породи до 50 та більше 50\%, а також бурої карпатської, виведеної в рівнинних $i$ гірських господарствах. Генетичну структуру очінювали за генетично детермінованим поліморфізмом груп генетикобіохімічних систем. Встановлено, що із 14 досліджуваних локусів, які кодують білки та ферменти крові, поліморфізм був виявлений у п'яти локусах, а саме: трансферину (Тf), церулоплазміну (Ср), амілази-1 (Ат-1), гемоглобіну (Нb) $і$ пуриннуклеозидфосфорилази (NP). У результаті популячійно-генетичного аналізу поліморфних локусів білків і ферментів крові у тварин бурої карпатськоі породи одержані такі дані: найбільш високий рівень гетерозиготності (Н) виявлений за локусом трансферину - 95\%, а наймениий - за локусом гемоглобіну - 9,5\%. Гетерозиготність за локусом церулоплазміну складала 68\%. Оцінка гетерозиготності за локусом пуриннуклеозидфосфорилази була неможлива, оскільки частина тварин з фенотипом NP-H (висока активність) могла нести в гетерозиготному стані варіант з низькою активністю. За всіма поліморфними системами у бурої карпатської породи розподілу частот генотипів знаходилася у врівноваженому стані у відповідності з законом Харді-Вайнберга, крім локусу трансферину, де виявлена статично достовірна недостача гомозигот (P>0,95) за найбільш розповсюдженими алельними варіантами. Аналіз дендрограми показав, щз групи тварин бурої карпатської породи з різною часткою спадковості швіцької утворюють один кластер, який чітко диференціюється від чистопородніх швіців. Помісні тварини першого покоління ( $\left.F_{1}\right)$ за генетичною структурою суттєво ближче до материнської бурої карпатської породи, ніж до ивіцької. Таким чином, одержані дані свідчать, щзо специфічною характеристикою бурої карпатської породи може бути відносно підвищена селекційна иінність ряду алельних міжлокусних асоціацій, в які тим чи іншим шляхом втягуються розглянуті локуси генетико-біохімічних систем. Генетичний аналіз за даними системами показав наявність у досліджуваної породи своӥх специфічних особливостей, які характерні тільки для неї.

Ключові слова: популяція, порода, бура карпатська, швіцька, помісі, маркери, локус, алелі, гетерозиготність.

\section{Вступ}

Проблема збереження порід сільськогосподарських тварин існує у всіх країнах світу, оскільки процес зникнення за певних причин спостерігається практично повсюдно. Це не тільки втрата об'єктивно безцінної генетичної та біологічної різноманітності, що актуально також у зв'язку 3 антропогенним тиском i для диких видів, але і звуження генетичного потенціалу, який принципово обмежує можливості селекційної роботи в майбутньому. Останнім часом стає все більш очевидною необхідність збереження генетичної різноманітності, а саме в зв'язку з особливостями ведення господарства в різних еколого-географічних регіонах. Уявлення про те, що високопродуктивні тварини або їх помісі $з$ місцевими локальними породами зберігають свою продуктивність в різних регіонах не завжди справджується (Glazko et al., 2005; Hlestkina, 2013; Bodnaruk et al., 2017).

Вивчення генетичної структури великої рогатої худоби дає змогу охарактеризувати ії за молекулярногенетичними маркерами, які в подальшому дають можливість проведення ефективної селекційної роботи 3 породами тварин, спрямованої на досягнення значних показників продуктивності. Для досягнення бажаних параметрів породи необхідно враховувати генофонди вихідних племінних плідників, а також інтегральні показники “екологічного благополуччя" господарств, в яких планується їх розміщення для подальшого розведення (Bochkov et al., 2015; Bodnaruk et al., 2016; Bodnaruk et al., 2017).

Крім того, актуальність дослідження генетичної структури локальних порід стає особливо гострою в зв'язку з необхідністю розробки генетично обгрунтованих програм збереження їх генофондів і використання при одержані нових типів і груп тварин, адаптованих до певних умов розведення, що відповідають сучасним вимогам технологізації та інтенсифікації сільськогосподарського виробництва (Shcherbatyj et al., 2016; Suprovich \& Mokhnachova, 2017). Виходячи 3 цього доцільним є створення банків даних про фенотипову та генотипову різноманітність локальних порід. Така інформація могла б бути використана також для вивчення питань щодо закономірностей і механізму генетичної дивергенції, мікроеволюції порід i видів тварин. Таким чином, для того, щоб виявити внесок у розмах генетичної мінливості в різних еколого-географічних зонах, нами проведено дослідження 3 вивчення генетичної структури тварин бурої карпатської і швіцької порід, їх помісей з різними частками спадковості, а також бурої карпатської, виведеної в рівнинних і гірських господарствах.

\section{Матеріал і методи досліджень}

Генетичну структуру оцінювали за генетично детермінованим поліморфізмом груп генетикобіохімічних систем. Досліди проводились на еритроцитах і плазмі крові. Кров у тварин брали з яремної вени в пробірку з гепарином. Поліморфізм білків та ферментів оцінювали, застосовуючи метод електрофоретичного розділення білків у 13\% крохмальному гелі в горизонтальних мікро та звичайних камерах 3 подальшим гістохімічним фарбуванням (Harris \& Hopkinson, 1976).

Досліджувані тварини були поділені на ряд груп: чистопородна бура карпатська і швіцька породи та їх помісі, зокрема півкровні тварини (1/2БК+1/2Ш гетерозигота), група 1 - 3 перевагою (більше 50\%) швіцької “крові”, група 2 - 3 меншою часткою (менше 50\%) швіцької “крові”, група 3 - бура карпатська виведена в рівнинних умовах, група 4 - бура карпатська виведена в гірських господарствах.

До групи досліджуваних генетико-біохімічних систем входили транспортні білки: церулоплазмін і трансферин; фермент метаболізму пуриннуклеозидфосфорилаза. Розрахунок генетичних відстаней та кластерний аналіз поліморфних локусів виконаний за методом М. Нея (Nei, 1972) при використанні комп'ютерної програми “BIOSYS”. 


\section{Результати та їх обговорення}

Встановлено, що із 14 досліджуваних локусів, які кодують білки та ферменти крові, поліморфізм був виявлений у п'яти локусах, а саме: трансферину, церулоплазміну, амілази-1, гемоглобіну і пуриннуклеозидфосфорилази (табл. 1).

Трансферин (Tf). У тварин бурої карпатської породи у цьому локусі виявлено чотири алельних варіанти: Tf A, Tf D1, Tf D2, Tf Е. Три алельні варіанти зустрічаються приблизно 3 однаковою частотою в бурої карпатської породи (Tf A - частота прояву 0,381; Tf D1 - 0,238; Tf D2 - 0,357). Найменша частота притаманна алелю Tf E $(0,024)$.

Церулоплазмін (Ср). У цьому локусі спостерігали три генотипи - Cp AA, Cp BB, Cp AB. В групі чистопородних тварин бурої карпатської породи переважав алель Сp A $(0,553)$.

Амілаза-1 (Am-1). При аналізі фореграм було виявлено три генотипи - Am-1 BB, Am-1 CC, Am-1 BC. Найвищою частотою відзначалась алель Am-1 B $(0,737)$.

\section{Таблиця 1}

Генетична структура бурої карпатської і швіцької порід та їх помісей за поліморфними генетико-біохімічними системами

\begin{tabular}{|c|c|c|c|c|c|c|c|c|}
\hline Локуси & $\begin{array}{l}\text { Гено- } \\
\text { типи }\end{array}$ & $\begin{array}{c}\text { Швіцька } \\
\text { порода (Ш) }\end{array}$ & $\begin{array}{c}\text { Бура карпат- } \\
\text { ська порода } \\
\text { (БК) }\end{array}$ & $\begin{array}{c}\text { Гетеро- } \\
\text { зигота } \\
(1 / 2 Б К+1 / \\
Ш)\end{array}$ & $\begin{array}{c}\text { Група } 1 \\
\text { (більше 50\% } \\
\text { швіцької } \\
\text { крові) }\end{array}$ & $\begin{array}{c}\text { Група } 2 \\
\text { (менше 50\% } \\
\text { швіцької } \\
\text { крові) }\end{array}$ & $\begin{array}{c}\text { Група } 3 \text { (БК, } \\
\text { виведена в рів- } \\
\text { нинних районах) }\end{array}$ & $\begin{array}{c}\text { Група } 4 \text { (БК, } \\
\text { виведена в } \\
\text { гірських райо- } \\
\text { нах) }\end{array}$ \\
\hline \multirow{9}{*}{$\begin{array}{c}\text { TF } \\
\text { Генотипи } \\
(\%)\end{array}$} & AA & 8 & - & 7 & 11 & 8 & 7 & 8 \\
\hline & AD1 & - & 28 & 26 & 33 & 8 & 26 & 8 \\
\hline & $\mathrm{AD} 2$ & 36 & 43 & 26 & 22 & 58 & 20 & 67 \\
\hline & $\mathrm{AE}$ & - & 5 & 7 & - & - & 7 & - \\
\hline & D1D1 & 8 & - & 7 & - & - & 7 & - \\
\hline & D1D2 & 11 & 19 & 7 & 22 & 8 & 7 & 8 \\
\hline & D1E & - & - & 7 & - & - & 7 & - \\
\hline & D2D2 & 33 & 5 & 13 & - & 17 & 20 & 8 \\
\hline & $\mathrm{D} 2 \mathrm{E}$ & 3 & - & - & 11 & - & - & - \\
\hline \multirow{4}{*}{ Алелі } & $\mathrm{A}$ & 0,264 & 0,381 & 0,367 & 0,389 & 0,417 & 0,333 & 0,458 \\
\hline & D1 & 0,139 & 0,238 & 0,267 & 0,278 & 0,083 & 0,267 & 0,083 \\
\hline & D2 & 0,583 & 0,357 & 0,300 & 0,278 & 0,500 & 0,333 & 0,458 \\
\hline & $\mathrm{E}$ & 0,014 & 0,024 & 0,067 & 0,056 & - & 0,067 & - \\
\hline \multirow{3}{*}{$\begin{array}{l}\text { СР Гено- } \\
\text { типи (\%) }\end{array}$} & AA & 32 & 21 & 27 & 56 & 50 & 40 & 34 \\
\hline & $\mathrm{AB}$ & 53 & 68 & 67 & 33 & 50 & 60 & 58 \\
\hline & $\mathrm{BB}$ & 15 & 11 & 6 & 11 & - & - & 8 \\
\hline \multirow{2}{*}{ Алелі } & A & 0,588 & 0,553 & 0,600 & 0,722 & 0,750 & 0,700 & 0,625 \\
\hline & $\mathrm{B}$ & 0,412 & 0,447 & 0,400 & 0,278 & 0,250 & 0,300 & 0,375 \\
\hline AM-I & BB & 57 & 58 & 53 & 78 & 50 & 60 & 42 \\
\hline \multirow{2}{*}{$\begin{array}{c}\text { Генотипи } \\
(\%)\end{array}$} & $\mathrm{BC}$ & 33 & 32 & 27 & 11 & 50 & 20 & 58 \\
\hline & $\mathrm{CC}$ & 10 & 10 & 20 & 11 & - & 20 & - \\
\hline \multirow{2}{*}{ Алелі } & $\mathrm{B}$ & 0,738 & 0,737 & 0,667 & 0,833 & 0,750 & 0,700 & 0,708 \\
\hline & $\mathrm{C}$ & 0,262 & 0,263 & 0,333 & 0,167 & 0,250 & 0,300 & 0,292 \\
\hline \multirow{2}{*}{$\begin{array}{l}\text { НВ Гено- } \\
\text { типи (\%) }\end{array}$} & AA & 47 & 90 & 80 & 78 & 92 & 73 & 100 \\
\hline & $\mathrm{AB}$ & 53 & 10 & 20 & 22 & 8 & 27 & - \\
\hline \multirow{2}{*}{ Алелі } & $\mathrm{A}$ & 0,736 & 0,952 & 0,900 & 0,889 & 0,958 & 0,867 & 1,000 \\
\hline & $\mathrm{B}$ & 0,264 & 0,048 & 0,100 & 0,111 & 0,042 & 0,133 & - \\
\hline \multirow{2}{*}{$\begin{array}{l}\text { PN Гено- } \\
\text { типи (\%) }\end{array}$} & $\mathrm{L}$ & 72 & 67 & 60 & 67 & 58 & 60 & 58 \\
\hline & $\mathrm{H}$ & 28 & 33 & 40 & 33 & 42 & 40 & 42 \\
\hline
\end{tabular}

Гемоглобін $(\mathrm{Hb})$. Нами було виявлено два генотипи - Нb АА та Нb АВ, не було виявлено в породі гомозигот Нb ВВ. У бурої карпатської породи найбільш розповсюджений алель $\mathrm{Hb}$ А $(0,952)$, що являється характерним для європейських порід.

Пуриннуклеозидфосфорилаза (NP). За локусом NP у бурої карпатської породи на фореграмах спостерігали два фенотипи, які суттєво відрізнялися за активністю: високою (Н) і низькою (L). В дослідженій групі чистопородних тварин бурої карпатської породи найбільш часто зустрічався фенотип з низькою активністю NP-L $(0,667)$.
У результаті популяційно-генетичного аналізу поліморфних локусів білків і ферментів крові у тварин бурої карпатської породи одержані такі дані: найбільш високий рівень гетерозиготності $(\mathrm{H})$ виявлений за локусом трансферину - 95\%, а найменший - за локусом гемоглобіну - 9,5\%. Гетерозиготність за локусом церулоплазміну складала 68\%. Оцінка гетерозиготності за локусом пуриннуклеозидфосфорилази була неможлива, оскільки частина тварин з фенотипом NP-H (висока активність) могла нести в гетерозиготному стані варіант $з$ низькою активністю. За всіма поліморфними системами у бурої карпатської породи розподілу частот генотипів знаходилася у врівнова- 
женому стані у відповідності 3 законом ХардіВайнберга, крім локусу трансферину, де виявлена статично достовірна недостача гомозигот $(\mathrm{P}>0,95)$ за найбільш розповсюдженими алельними варіантами.

3 метою вивчення взаємовідносин чистопородних тварин і помісного потомства був виконаний порівняльний аналіз генетичної структури чистопородної бурої карпатської (БК) і швіцької порід (Ш) та їх потомства різної кровності. За алельними частотами швіцька порода суттєво відрізнялася від тварин бурої карпатської тільки за локусом TF I HB. У швіцької породи відносно бурої карпатської частіше зустрічались алельні варіанти Tf D2, Hb B і рідше Tf D1. За локусом НВ генетична структура груп помісних тварин чітко відповідала особливостям їх походження помісі $з$ перевагою крові швіців (група 1) були подібні 3 чистопородними швіцами і відрізнялися від інших груп підвищеною частотою проявлення алельного варіанту $\mathrm{Hb} \mathrm{B}$.

У тварин 3 перевагою крові бурої карпатської (група 2) також найнижча частота прояву $\mathrm{Hb} \mathrm{B}$, як і у чистопородної бурої карпатської. За локусом ТF, навпаки, група 2 за розподіленням алельних частот виявилась більш подібною з чистопородними швіцами, а група 1 - 3 чистопородною бурою карпатською. Відмінності, що спостерігалися, можуть бути зумовлені рядом обставин, а саме: випадковими стохастичними процесами в малих вибірках та впливом на генетичну структуру досліджених тварин різних умов розведення в господарствах гірських і рівнинних зон. Для того, щоб оцінити вплив на генетичну структуру двох груп помісних $\left(\mathrm{F}_{1}-3\right.$ перевагою крові бурої карпатської породи), виведених в умовах рівнинного (група 3) і гірського (група 4) господарств одержані дані представлені в таблиці.

Незважаючи на невелику кількість тварин і їх помісне походження видно, що між двома цими групами (група 3 i 4) диференціація за генетичною структурою спостерігається, в основному, по тих самих локусах TF i Hb. В рівнинних зонах (група 3) відносно частіше, ніж у гірських (група 4) проявляється гомозигота D2D2 і гетерозигота $\mathrm{Hb} \mathrm{AB}$, а в гірській - гетерозигота TF AD2 і гомозиготи Нb AA. У бурої карпатської породи вищий рівень середньої гетерозиготності на поліморфних локусах в порівнянні з швіцами $(0,410$ i 0,378) так само, як і у гірської групи в порівнянні 3 рівнинною $(0,400$ і 0,347$)$. При цьому в обох випадках однакові причини відмінностей середньої гетерозиготності - у чистопородної бурої карпатської породи і помісей гірської групи тварин вища гетерозиготність локусу TF $(0,952$ і 0,833$)$, ніж у швіців і рівнинної групи $(0,500$ i 0,667), а нижча за локусом $\mathrm{Hb}$ (бура карпатська і гірські помісі - 0,095 і 1,000; швіци і рівнинна група - 0,528 і 0,267). Одержані дані дозволять припустити, що різні еколого-географічні умови розведення тварин вносять певний внесок (але не визначать повністю) у диференціацію генетичних структур досліджуваних чистопородних і помісних тварин.

На основі алельних частот поліморфних генетикобіохімічних систем були розраховані генетичні дистанції (за стандартним методом М. Нея (Nei, 1972) i використаний кластерний аналіз між чистопородними і помісними тваринами. Одержані результати представлені на дендрограмі (рис. 1).

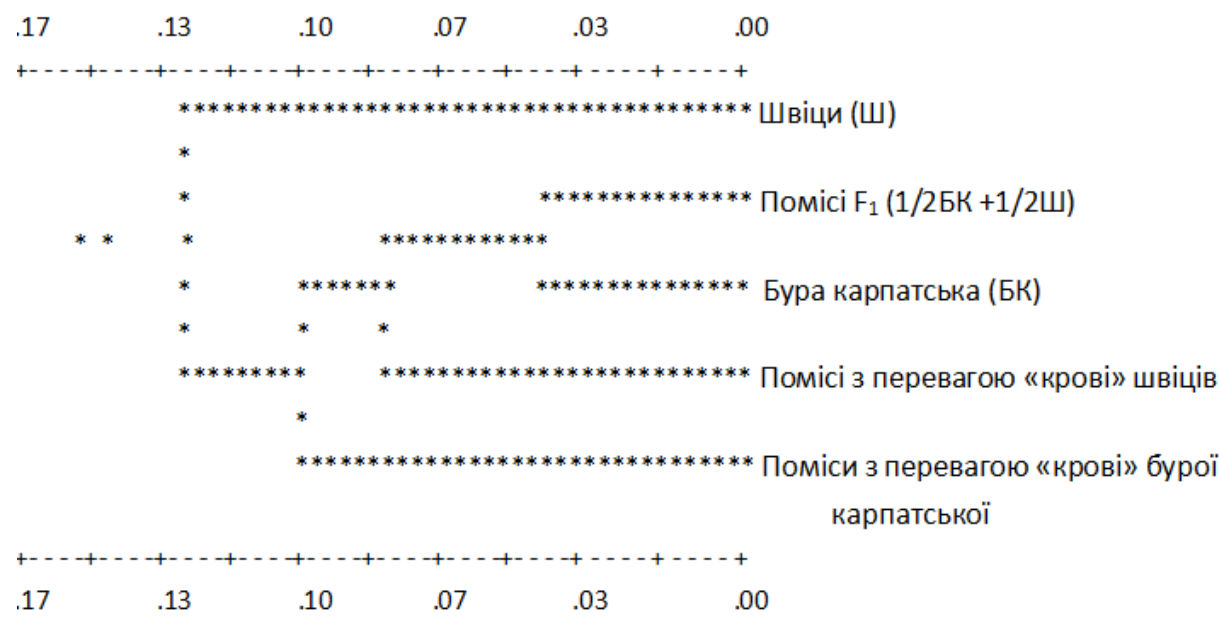

Рис. 1. Дендрограма генетичних взаємовідносин між досліджуваними групами тварин

Аналізуючи дану дендрограму можемо відзначити, що групи тварин різних помісей з участю бурої карпатської породи утворюють один кластер, який чітко диференціюється від чистопородніх швіців. Група помісних тварин першого покоління, одержаних від схрещування чистопородних, за генетичною структурою суттєво ближче до материнської бурої карпатської породи, ніж до швіцької.

Приймаючи до уваги, що швіцька порода історично брала участь у формуванні генофонду бурої кар- патської породи, одержані дані можуть свідчити про підвищений консерватизм їі генетичної структури за генетико-біохімічними системами, який зберігається навіть при “прилитті крові” генетично близької породи.

\section{Висновки}

Виходячи з одержаних даних, можна говорити, що специфічною характеристикою бурої карпатської 
породи може бути відносно підвищена селекційна цінність ряду алельних міжлокусних асоціацій, в які тим чи іншим шляхом втягуються розглянуті локуси генетико-біохімічних систем. Генетичний аналіз за даними системами показав наявність у досліджуваної породи своїх специфічних особливостей, які характерні тільки для неї.

Перспективи подальших досліджень. На основі даних досліджень можна проводити спрямовану та інтенсивнішу селекцію різних порід сільськогосподарських тварин з одержанням бажаного результату.

\section{References}

Bochkov, V.M., Gorodna, O.V., \& Tarasjuk, S.I. (2015). Porivnjal'nyj analiz genetychnoi' struktury okremyh grup golshtyns'koi' porody velykoi' rogatoi' hudoby. Rozvedennja i genetyka tvaryn, 49, 164-168. http://er.nau.edu.ua:8080/handle/NAU/34834 Ukrainian).

Bodnaruk, V.Y., $\quad$ Muzyka, L.I., $\quad$ Zhmur, A.J., $\quad$ \& Orikhivskyy, T.V. (2016). Comparative analysis of genetic and parental hybrids. Scientific Messenger LNUVMBT named after S.Z. Gzhytskyj, 18, 2(67), 21-24. doi: 10.15421/nvlvet6705.

Bodnaruk, V.Y., Muzyka, L.I., Bodnar, P.V., Zhmur, A.J., \& Orihivsjkyj, T.V. (2017). New possibilities of effective breeding in cattle based on the study of the genome. Scientific Messenger LNUVMB, 19(79), 3237. doi: 10.15421/nvlvet7907.

Bodnaruk, V., Shchebatyj, Z., Muzyka, L., Zhmur, A., \& Orikhivskyj, T. (2017). Genofond of some breed of cattle. Scientific Messenger LNUVMBT named after S.Z. Gzhytskyj, $19 \quad$ (74), 131-134. doi: $10.15421 /$ nvlvet7429.

Glazko, T.T., Zubec, M.V., Tarasjuk, S.I. i dr. (2005). Geneticheskaja komponenta bioraznoobrazija krupnogo rogatogo skota. Kiev: KVIC, 111-121 (in Russian).

Harris, H., \& Hopkinson, D.A. (1976). Handbook of enzyme electrophoresis in human genetics. Amsterdam: North-Holland Publ. Comp.

Hlestkina, E.K. (2013). Molekuljarnye markery v geneticheskih issledovanijah i v selekcii. Vavilovskij zhurnal genetiki i selekcii, 17(4/2), 1044-1054 (in Russian).

Nei, M. (1972). Genetic distance between populations. The American Naturalist, 106, 283-292.

Shcherbatyj, Z.Y., Kozenko, O.V., Bodnaruk, V.Y., Muzyka, L.I., Zhmur, A.J., \& Orikhivskyy, T.V. (2016). Ukrainian gray breed of cattle. Scientific Messenger LNUVMB, 18, 1(65), 3, 173-177. https:/nvlvet.com.ua/index.php/agriculture/article/vie w/3523/3491 (in Ukrainian).

Suprovich, T., \& Mokhnachova, N. (2017). Gene polymorphism of economically-useful traits in ukrainian gray cattle breed. The Animal Biology, 19(1), 111118. doi: 10.15407/animbiol19.01.111. 